\section{THE ELECTRIC LIGHT AT THE BRITISH MUSEUM.}

THE authorities of the British Museum are to be congratulated on the thorough and admirable manner in which the scheme for the electric lighting of the galleries has been carried out. Everyone present at the private view on Tuesday evening was pleased with the results which had been achieved. Both arc and glow lamps are employed; the former in the galleries on the ground floor containing Greek and Roman sculpture, the Eigin marbles, and Assyrian and other antiquities, and in some galleries on the upper floor. The suite of bronze and vase rooms on the west, and the ethnographical gallery on the east, of the upper floor are lighted by glow lamps. The light from glow lamps is more agreeable to the eyes than the more powerful light of arc illuminants but these have been regulated with the utmost care, and on Tuesday evening there was a very general feeling that the beauties of the sculpture were brought out by theirn more effectually than by such daylight as is at times rendered possible by our northern climate. With regard to the arc lights on the upper floor, it was noticed that they were admirably adapted for the exhibition of the Japanese drawings, even the minutest details of these delicately finished works being rendered plainly visible without any diminution of the beauty of the colours.

We quote from the Times of January 29 the following description :-

"In the galleries on the ground floor there are 69 arc lamps of various powers, while on the upper floor there are 57 arc and 627 glow lamps. In addition to these there are five large arc lamps in the reading-room, six in the court-yard, and upwards of 200 glow lamps in the offices and passages. The total current required to work the whole of the lamps is nearly 1200 amperes, with an E.M.F. of II 5 volts at the lamp terminals; and this output is produced by the expenditure of nearly 200 brake-horsepower. The current is generated by four Siemens dynamo machines, each capable of giving an output of 450 amperes and 130 volts, which are connected to a general switchboard in the engine-room by means of which they can be put to work in parallel to any or all of the circuits. The switchboard is fitted with instruments indicating the current given off by each dynamo and four circuits are led from it round the Museum-two for the upper and two for the lower floor. The main wires are laid outside the building. In order to insure safety, and to guard, as far as possible, against failure of light, the motive power is in duplicate. The four dynamos are driven in pairs, each pair by a separate engine with a separate countershaft. Each engine has a separate steampipe in dis ect communication with the boilers, and there is an ample reserve of boiler power The power of the engines and dynamos is so adjusted that each of the two sets is capable of working the whole of the lamps in those galleries proposed to be lighted on any one evening; the other set standing by ready to work. Further, in order to work if required, at half-power, or in order to provide half-light for the whole of the gallerieswhich light should suffice for an emergency such as sudden fog or accident - the lamps are connected in pairs alternately, so that half of the number being cut off, the light of the other half still remains evenly distributed. The engines have been supplied and erected by Messrs. Marshall, Sons, and Co. (Limited), of Gainsborough, and the electrical work has been executed by Messrs. Siemens Brothers and Co. (Limited)."

The eastern and western portions of the Museum will be open to the public on alternate week-day evenings, and all the world agrees with the Times that " the educational value of the unique collections of art and scientific treasures the Museum contains will be greatly enhanced by the change."

\section{NOTES.}

THE Medals and Funds to be given at the anniversary meeting of the Geological Society on February 2I have been awarded by the Council as follows: the Wollaston Medal to Prof. William Crawford Williamson, F.R.S. ; the Murchison Medal to Prof. Edward Hull, F.R.S.; and the Lyell Medal to Prof. Thomas Rupert Jones, F.R.S. ; the balance of the Wollaston Fund to Mr. W. E. A. Ussher, of the Geological Survey of England ; that of the Murchison Fund to Mr. Edward Wethered; that of the Lyell Fund to Mr. C. Davies Sherborn; and a portion of the Barlow-Jameson Fund to Mr. William Jerome Harrison.

The Council of the Royal Meteorological Society have arranged to hold at 25 Great George Street, Westminster, on March 18 to 2 I next, an Exhibition of Instruments and Photographs illustrating the application of photography to meteorology. The Exhibition Committee invite co-operation, as they are anxious to obtain as large a collection as possible. They will also be glad to show any new meteorological instruments or apparatus invented, or first constructed, since last March; as well as photographs and drawings possessing meteorological interest. Anyone willing to co-operate in the proposed Exhibition should furnish the assistant secretary (not later than February I2) with a list of the articles he will be able to contribute and an estimate of the space they will require.

THE second course of the Gifford Lectures at Glasgow will begin on February 5. As announced in the first course, these lectures will treat of what Prof. Max Miiller calls "Physical Religion," or the belief in natural, sub-natural, and super-natural powers, discovered in some of the great phenomena of Nature.

SOME most interesting notes on the last days of Father Perry are contributed to the Tablet of January 25 by Father Strickland, S.J. The facts stated by the writer bring out in a very striking light the earnest and resolute spirit in which, to the end of his life, Father Perry devoted himself to science. During the voyage he suffered badly from sea-sickness, and on his arrival at the Isles de Salut he was " much done up." Nevertheless, he allowed himself no rest, but landed at once to view the site and introduce himself to the authorities. Captain Atkin son urged him to live on board the Comus and land each morning for his work; and Father Strickland is of opinion that if he had done this "his life would not have been sacrificed to his overanxious desire to do everything for the best for the success of the work confided to him." He preferred, however, to take up his quarters in the hospital, and said nothing about the fact that he was in bad health, making "light of all his personal wants for fear of giving trouble to others." The observatory erected for the occasion was half a mile from the hospital, and "the intervening ground was very rough, being a steep descent and ascent, and the distance was gone over on foot four times each day in fair weather or foul." "On the Friday before the eclipse Father Perry complained of being 'very bad inside,' but he worked on until nearly $3 \mathrm{a} . \mathrm{m}$., and when the men retired to the Comus he tried to snatch a little rest where he was, and lay down in a hammock in the tent. $\mathrm{He}$ was up again before 6 o'clock to take the position of the sun at rising. At 6.45 the men arrived from the ship, and at 7.30 there was a complete, most careful, and most successful rehearsal of all the operations and duties which were to be performed next morning in the solemn moments of the eclipse, for which they had been preparing so long and had travelled so far. Everyone was surprised at Father Perry's exactitude in contributing to carry out his own orders and his courage in facing fatigue. His readiness to sacrifice himself and his own convenience in order to save trouble to others endeared him to all who worked with him, and challenged their utmost efforts to secure success for their work in 